\title{
The Product and Sector Level Impact of a Hard Brexit across the EU
}

\author{
Martina Lawless $^{\mathrm{a}, \mathrm{b}}$ and Edgar L. W. Morgenroth ${ }^{\mathrm{c} *}$ \\ a) Economic and Social Research institute, Whitaker Square, Sir John Rogerson's Quay, \\ Dublin, D02K138, Ireland \\ b) Department of Economics, Trinity College, College Green, Dublin 2 Ireland \\ c) DCU Business School, Dublin City University, Glasnevin, Dublin 9, Ireland \\ * Corresponding author: e-mail: edgar.morgenroth@dcu.ie. Tel. +353 17005252
}

\begin{abstract}
The UK exit from the European Union (Brexit) is likely to have a range of impacts, with trade flows one of the most immediate areas where the effects will become evident. One possible outcome of Brexit is a situation where WTO tariffs apply to merchandise trade between the UK and the EU. By examining detailed trade flows between the UK and all other EU members, matching over 5200 products to the WTO tariff applicable to external EU trade this paper shows that such an outcome would result in significantly different impacts across countries. Our estimates of exposure at the country level show an extremely wide range with reductions in trade to the UK falling by 5\% (Finland) to $43 \%$ (Bulgaria) taking into account the new tariffs and the elasticity of the trade response to this price increase. Food and textiles trade are the hardest hit, with trade in these sectors reducing by up to $90 \%$.
\end{abstract}

Key Words: Brexit, WTO tariffs, merchandise trade

JEL Classification: F13, F14, F17 


\section{Introduction}

The decision of the UK electorate to leave the EU is likely to have wide ranging impacts on the relationship between the UK and other EU member states. Understanding the voter motivation driving the referendum result and potential knock-on effects in other countries was one of the most immediate questions raised (Hobolt, 2016, Los et al. 2017). In addition to the political questions raised, the economic effects are likely to be considerable and wide-ranging coming from changes in the degree of freedom of trade between the UK and the EU, changes in investment patterns and barriers to the movement of labour. Most of the pre-referendum research focused on the potential impact on the UK. Less analysis has been carried out on the wider impact of Brexit across the EU, perhaps as it had been anticipated that the referendum result would confirm the continued UK membership of the EU.

The focus of most existing research on Brexit has been on aggregate impacts across the economy. Much of this builds on existing research that has demonstrated the positive effects of free trade agreements on trade flows, such as that of Caporale et al. (2009) on the expansion of the EU to include countries in Central and Eastern Europe. Both the UK Treasury (see HM Treasury, 2016a,b) and the UK National Institute of Economic and Social Research (NIESR) (see Baker et al. 2016, Ebell and Warren, 2016) used the NIESR NiGEM model to estimate the macroeconomic impact of Brexit on the UK. The NiGem model, which is a world model, was also used to assess the implications of Brexit across OECD countries (Kierzenkowski et al. 2016) while the EU Commission used their QUEST dynamic stochastic general equilibrium model to estimate the impact on the EU (EC, 2016). The macroeconomic implications on some individual EU member states such as the Netherlands (Bollen et al., 2016) and Ireland (Bergin et al, 2017) have also been estimated.

As the ultimate agreement on the future relationship between the UK and the EU is at this point not known, the existing studies have assessed the impact under different scenarios that cover a spectrum of possible outcomes. These typically encompass agreements such as that between Norway and the EU (EEA), those between Switzerland and the EU (EFTA) and, as a worst case scenario, where the WTO tariffs apply to merchandise trade. The recent policy paper by the UK government on future customs arrangements re-iterates that the UK will leave both the EU Single Market and the Customs Union (HM Government, 2017), and at the time of writing progress in the exit negotiations has been slow and there is a possibility that these negotiations might fail. Both make a "WTO" outcome more likely. 
This paper uses detailed tariff information to generate estimates of the fall-back "hard Brexit" outcome of applying the EU's tariff schedule on third countries as registered with the World Trade Organisation (WTO) to trade between the EU and UK.

The WTO tariffs vary widely across products with many subject to a zero tariff while some products are subject to a tariff as high as $75 \%$ (for water pipe tobacco). Many basic products and commodities are subject to both an ad valorem tariff and a weight based tariff which often results in high overall levels of tariff. This implies that the aggregate impact of Brexit under a WTO scenario is a function of the detailed trade patterns and the impact will thus vary considerably across EU member states. For the UK the most important EU trading partners are Germany (10.2\% of total merchandise exports) and France (5.9\%) while countries such as Croatia $(0.05 \%)$ or Latvia $(0.07 \%)$ are less important. For countries such as Ireland (13.7\%) and Cyprus (10.1\%) the UK is a particularly important destination of merchandise exports while for others such as Croatia (1.7\%) or Slovenia $(2.2 \%)$ the UK is not a particularly important trading partner.

Barrett et al. (2015), in their study of the potential impact of Brexit on Ireland, highlight the significant concentration of Irish exports to and imports from the UK in a small number of products, some of which are subject to heterogeneity across sectors and products. Agri-food sector product trade in particular has been identified as being vulnerable to a WTO arrangement between the UK and the EU (see Matthews, 2015, Donnellan and Hanrahan, 2016).

However, aggregate studies tend to ignore the impact of the heterogeneity of the tariffs and trade patterns. For example Bollen et al. (2016), in their analysis of the impact of Brexit on the Netherlands, assume a tariff rate of 3\% across all trade in their WTO scenario. This paper addresses this shortcoming in the literature by analysing the potential impact of the imposition of WTO tariffs at the 6 digit product level that encompasses 5205 product types, for both exports from the UK to other EU members and exports from EU members to the UK. The importance of taking into account the wide variation in tariffs across products is emphasised by Cipollina, Debucquet and Salvatici (2016), who examined the effect of the EU's existing preferential trade agreements and the potential TTIP (Transatlantic Trade and Investment Treaty) negotiations with the USA by analysing the product level tariff rates.

Building up the analysis from the product level allows us to control for the differences in trade patterns across countries as well as differences in tariffs and in the responsiveness of demand for different products to price changes. The results show the extent of heterogeneity of a WTO scenario on the individual trade flows between the UK and each EU member state. With tariff rates across sectors varying from $0 \%$ to $50 \%$, the tariff faced by each country depends crucially on the pattern of products traded. The total impact depends further on the elasticity of the trade flows and the share of each export partner in total trade flows. Overall reductions of $30 \%$ in EU to UK exports and $22 \%$ 
in $\mathrm{UK}$ to EU exports are computed based on conservative assumptions regarding the price responses across sectors to tariff increases. At a sector level, bilateral trade in food and textile products are close to being wiped out and trade in vehicles falls by over $60 \%$. For EU countries exporting to the UK, the fall in trade ranges from 5\% to $40 \%$. For the UK, the dispersion around the average fall of $22 \%$ is more limited but the total impact on its world trade is larger given that its faces reductions in trade with multiple export partners.

The paper is organised as follows: Section 2 provides a brief overview of the current trade structure between the EU and UK. Section 3 describes the WTO tariff structure and presents implied tariffs by country and sector if these were applied to the current trade structure between the UK and each of the other EU member states. Section 4 then examines what the implications for export flows might be of these tariff-induced price increases. Section 5 concludes.

\section{Trade between the EU and UK}

Our analysis is based on bilateral trade flows between the UK and each of the 27 other member states of the EU from the United Nations ComTrade data source for 2015. We also downloaded the total world trade of each country to place the trade links between each member state and the UK in the context of their overall exports and imports. This data provides information on the value and unit or weight of over 5,200 product lines, defined at the HS 6-digit level. To give an example of the level of detail this represents, there are nine categories of milk varying by fat content and whether or not any sweetener has been added.

Each of the product lines is then matched to the external tariff applied by the EU to third country trade as registered with the World Trade Organisation (WTO), where there is no separately agreed trade agreement. In the event of a "hard" Brexit and no immediately agreed trade treaty, we assume these third country tariffs would be the fall-back or default position between the EU and UK. We further assume that these tariffs would be applied both by the EU and the UK. The UK's mirroring of the tariffs is perhaps a stronger assumption than that the EU would use these WTO tariffs as the default position, but we argue that it is a reasonable one for the short term as WTO rules require the same external tariffs to be applied to all members so, without an agreed trade deal, the UK will not be able to apply different tariffs to trade from the EU than it is willing to apply to all other countries.

Applying the tariffs to each product line by definition increases the price. To examine the impact this price increase is likely to have on trade flows, we combine the trade data with price elasticities of trade at a sector level from Imbs and Mejean (2016). We use these to present estimates of the effects of a WTO scenario not just on overall trade between the EU and UK but also how the 
impact varies across countries and across sectors. Combining this with the information on the importance of trade between each EU country and the UK gives a picture of the level of exposure of total trade flows that the implementation of the WTO tariff rates would have.

Before examining the effects of applying tariffs, Table 1 describes the current pattern of trade between the UK and each of the other EU member states. The first two columns present the UK's exports and imports with each EU member as a share of total UK-EU trade flows. Germany is by far the largest trading partner of the UK within the EU, representing $23 \%$ of the UK's exports to the EU and $26.5 \%$ of its imports. France, Ireland and the Netherlands are the next most important trading partners, each accounting for around $13 \%$ of the UK's exports to the EU.

Table 1: Pattern of Trade between EU Members and UK, 2015

\begin{tabular}{|c|c|c|c|c|}
\hline & $\begin{array}{r}\text { Share of UK } \\
\text { Exports to EU }\end{array}$ & $\begin{array}{r}\text { Share of UK } \\
\text { Imports from EU }\end{array}$ & $\begin{array}{r}\text { UK as share of } \\
\text { total exports }\end{array}$ & $\begin{array}{r}\text { EU member as } \\
\text { share of UK } \\
\text { total } \\
\end{array}$ \\
\hline Austria & $1.21 \%$ & $1.31 \%$ & $3.06 \%$ & $0.53 \%$ \\
\hline Belgium & $8.54 \%$ & $10.50 \%$ & $8.92 \%$ & $3.77 \%$ \\
\hline Bulgaria & $0.25 \%$ & $0.19 \%$ & $2.55 \%$ & $0.11 \%$ \\
\hline Cyprus & $0.28 \%$ & $0.03 \%$ & $10.07 \%$ & $0.12 \%$ \\
\hline Czech Rep. & $1.47 \%$ & $2.48 \%$ & $5.25 \%$ & $0.65 \%$ \\
\hline Germany & $23.01 \%$ & $28.34 \%$ & $7.43 \%$ & $10.16 \%$ \\
\hline Denmark & $1.71 \%$ & $1.63 \%$ & $6.36 \%$ & $0.75 \%$ \\
\hline Spain & $6.46 \%$ & $6.12 \%$ & $7.45 \%$ & $2.85 \%$ \\
\hline Estonia & $0.16 \%$ & $0.10 \%$ & $2.58 \%$ & $0.07 \%$ \\
\hline Finland & $1.01 \%$ & $0.82 \%$ & $4.94 \%$ & $0.45 \%$ \\
\hline France & $13.33 \%$ & $10.81 \%$ & $6.27 \%$ & $5.89 \%$ \\
\hline Greece & $0.66 \%$ & $0.36 \%$ & $4.25 \%$ & $0.29 \%$ \\
\hline Croatia & $0.10 \%$ & $0.07 \%$ & $1.72 \%$ & $0.05 \%$ \\
\hline Hungary & $0.96 \%$ & $1.15 \%$ & $3.88 \%$ & $0.42 \%$ \\
\hline Ireland & $12.56 \%$ & $5.05 \%$ & $13.66 \%$ & $5.55 \%$ \\
\hline Italy & $6.37 \%$ & $7.30 \%$ & $5.53 \%$ & $2.81 \%$ \\
\hline Lithuania & $0.20 \%$ & $0.34 \%$ & $4.46 \%$ & $0.09 \%$ \\
\hline Luxembourg & $0.16 \%$ & $0.14 \%$ & $3.88 \%$ & $0.07 \%$ \\
\hline Latvia & $0.16 \%$ & $0.16 \%$ & $5.12 \%$ & $0.07 \%$ \\
\hline Malta & $0.28 \%$ & $0.05 \%$ & $6.45 \%$ & $0.12 \%$ \\
\hline Netherlands & $12.97 \%$ & $12.73 \%$ & $8.98 \%$ & $5.73 \%$ \\
\hline Poland & $2.73 \%$ & $4.02 \%$ & $6.81 \%$ & $1.20 \%$ \\
\hline Portugal & $0.94 \%$ & $1.13 \%$ & $6.72 \%$ & $0.41 \%$ \\
\hline Romania & $0.73 \%$ & $0.78 \%$ & $4.36 \%$ & $0.32 \%$ \\
\hline Slovakia & $0.33 \%$ & $1.27 \%$ & $5.54 \%$ & $0.15 \%$ \\
\hline Slovenia & $0.15 \%$ & $0.18 \%$ & $2.23 \%$ & $0.07 \%$ \\
\hline Sweden & $3.25 \%$ & $2.93 \%$ & $7.19 \%$ & $1.44 \%$ \\
\hline Total & $100.00 \%$ & $100.00 \%$ & $6.99 \%$ & $44.16 \%$ \\
\hline
\end{tabular}


For most countries, the shares of exports and imports are very similar; Ireland is an exception in this regard as it buys a much larger share of the UK's exports to the EU than it accounts for in the UK's imports from the EU. This represents the integrated wholesale market between Ireland and the UK and the relative size disparity between the two countries. The last two columns place the importance of UK trade with each member state in the broader context of their total (i.e. world) trade. Looking first at the total trade flows, the UK is the destination for just under $7 \%$ of exports from EU countries. In contrast, the EU represents slightly over $44 \%$ of UK exports. Even though many (indeed, almost all) of the individual country observations show the UK as a more important share of total exports than they are as shares of UK imports, the totals of the two columns show a very different picture of the balance of trade. This is for the simple reason that the total for the UK as a share of EU exports is a weighted average of each of the 27 member states export flows, whereas the share of the EU in total UK exports is the sum of each of these 27 trade flows.

The importance of the UK in total trade for each member state gives a rather different picture of how a switch to a WTO tariff regime might affect different countries compared to looking at the shares of intra-EU trade only. Ireland now stands out as the most reliant on the UK market, followed by Cyprus, whereas Germany with its more global export reach is less vulnerable than the EU shares columns suggested.

\section{WTO Tariffs by Country and Sector}

The external WTO tariffs are levied on specific product lines and the variation is considerable. Of the 5,000 individual products that are listed with the WTO, the tariffs applied by the EU on nonmembers without a specific trade deal range from $0 \%$ to over $80 \%$. As a result, a WTO arrangement would impact trade quite differently across the current EU member states and across different sectors within each country. This section examines the differing WTO tariffs by product type shows how unevenly spread the implied price effects could be.

Tariffs can be applied in two different ways - most of the WTO tariff rates are ad valorem tariffs (i.e. charged as a percentage of the value of the goods being shipped) while others are applied as a charge per unit quantity or by weight. In some instances, the two methods are combined, as for example in the case of the tariff on fresh or chilled boneless bovine meat which is $12.8 \%$ of the value of the product plus $€ 303$ per $100 \mathrm{~kg}$. The WTO also allows minimum and maximum ranges of both these tariff types to be registered with it - in Figures 1 and 2, we show the range between the minimum and maximum rates. However, the subsequent analysis assumes that it would be the minimum rates that would be applied to EU-UK trade.

Figure 1 and Figure 2 show the implied tariff by country on UK to EU trade and EU to UK trade respectively by applying the WTO tariffs to the current structure of trade between the UK and 
EU. The colours of the columns show the share of the tariff accounted for by ad valorem tariffs and weight-based tariffs, with the light and dark blue adding up to the total minimum tariff and the additional ad valorem and weight-based elements of the maximum tariff shown by the light and dark green.

Overall, the application of WTO tariff rates on exports from the EU to the UK would result in an average (minimum) tariff of $4.1 \%$. The lowest tariff would be imposed by Luxembourg, which would charge just $2 \%$ on goods coming from the UK, whereas the tariff on the UK's exports to Ireland would be almost double the average at $6 \%$ (with a potential maximum value of $11.7 \%$ ). Before looking in more detail at the sectoral structure, we can infer from the share of ad valorem compared to weight-based tariffs that the structure of the trade with the UK is quite different across many of the member states. A large part of the variation between the upper and lower bounds comes from the share of largely weight-based tariffs which are consistently higher on agricultural and food products. These types of product account for a much higher share of some countries trade with the UK, primarily Ireland, Portugal and Cyprus, compared to the trade of other EU countries.

The same applies in the other direction, as shown in Figure 2. Overall, the implied tariff that would be imposed by the UK on goods coming from the EU would be higher than that applied in by the EU and there is also greater variation. The average minimum tariff would be $5.7 \%$, but tariffs imposed on imports from Denmark and Ireland would be over 10\% (with the maximum values potentially as high as $18 \%$ in the case of Ireland). Again large differences in the sectoral structures of the trade flows are hinted at by the relative balance between ad valorem and weight-based tariffs across the different countries. 
Figure 1: Implied Tariff on UK to EU Trade, by Tariff Type

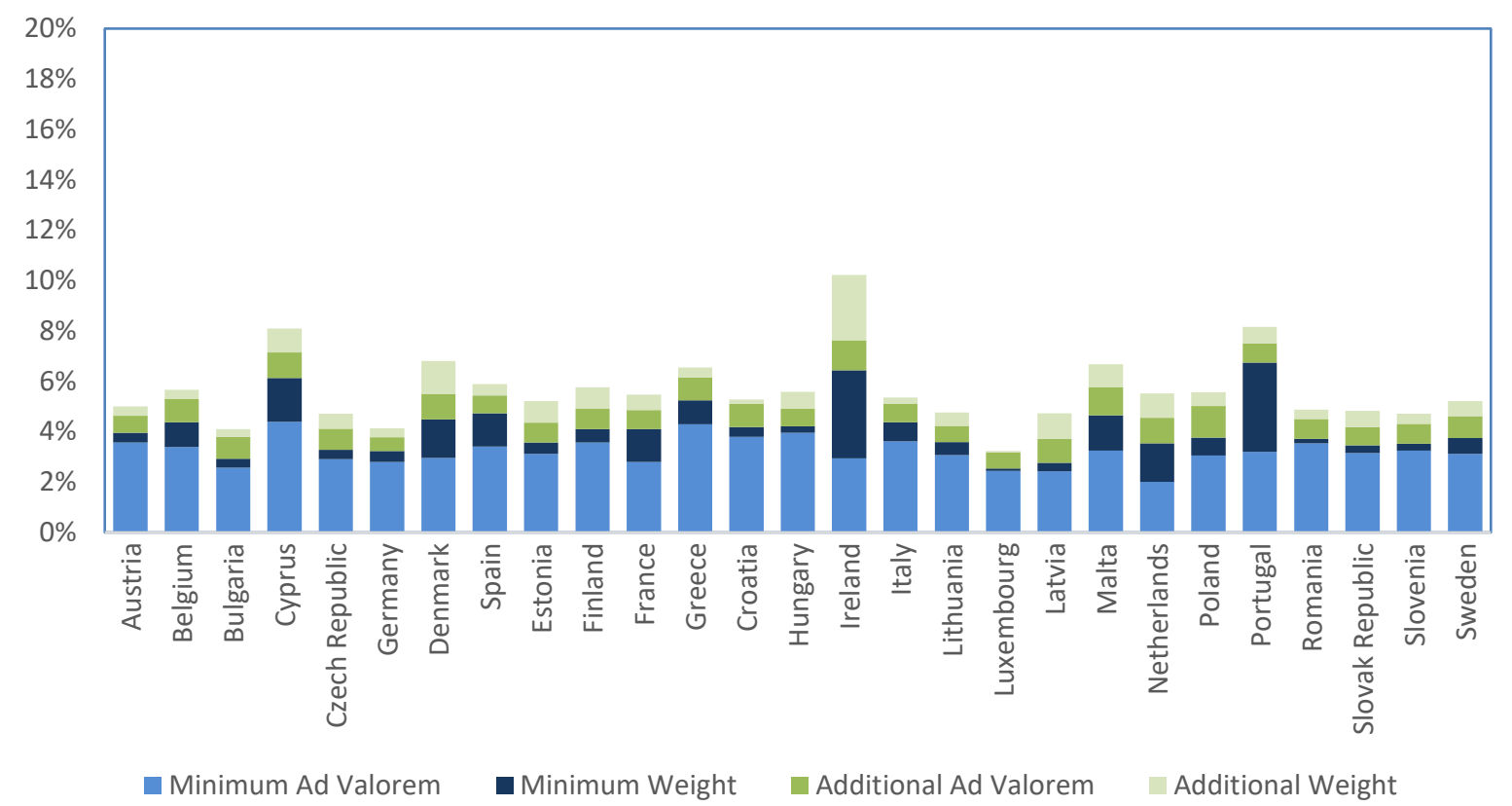

Figure 2: Implied Tariff on EU to UK Trade, by Tariff Type

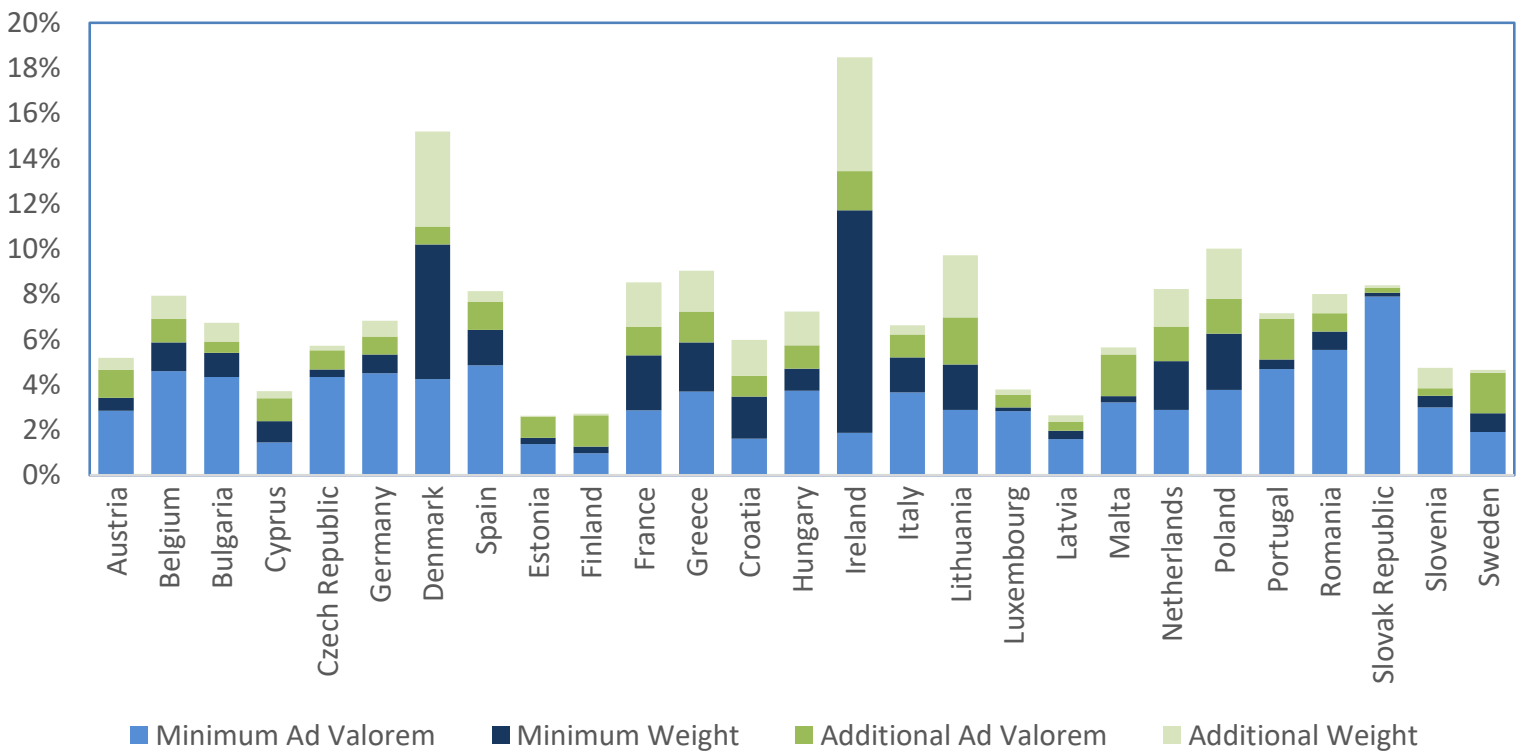

Before turning to this issue of sectoral variation in the tariff rates, we provide a calculation in Table 2 of how the variation in tariff rates across countries translate into different shares of tariff revenues owed to the UK and due from the UK and how these compare to the shares of each country in total EU-UK trade. In the absence of variation of tariffs across sectors, the shares of trade and tariffs should be the same. Overall there is a strong correlation between the two series, but there are some notable exceptions. Ireland in particular stands out in terms of tariff exposure on the UK's 
imports from the EU - it makes up 5\% of the UK's imports but would be charged close to $20 \%$ of the total EU tariff. Germany, on the other hand, would be liable for just under $18 \%$ of the tariff owed to the UK, despite accounting for over $28 \%$ of the trade flows.

The reason for this variation across countries reflects the very different tariff rates applied to products and hence the "implied" tariff rate per country is driven by its current structure of trade flows with the UK. The extent of the tariff variation across sectors is shown in Figure 3 (aggregated up to the HS 2-digit level). A number of sectors would face either no tariff at all or a rate set very close to zero: these include paper products, pharmaceuticals, iron and steel. Art and antiques are also charged a zero tariff rate although there may be other restrictions on their export if they are judged to be of national cultural value - this type of non-tariff barrier is beyond the scope of this paper.

There is a large intermediate set of sectors with tariff rates rising from $1 \%$ to around $10 \%$. There comes something of a step-change in the rates applied to the last 15 out of our 1002 -digit sectors, which face rates going from $10.3 \%$ on footwear to $49 \%$ on meat products. Recall that these are average rates for each sector and there may be further variation on individual products within each group - we gave an example earlier of a specific beef product with combined ad valorem and weight-based charges that came to an equivalent tariff of almost $80 \%$.

The fifteen sectors in the high tariff category all fall within the broader headings of food, clothes and tobacco products. Countries in the EU either exporting or importing these products to and from the UK face very different tariff barriers from those producing other types of manufactured products and particularly those exporting higher technology products such as electrical and telecommunications equipment or precision instruments which attract tariffs not far from $1 \%$. 
Table 2: Trade Shares and Share of Tariff Flows

\begin{tabular}{lrrrr}
\hline & $\begin{array}{r}\text { Share of UK } \\
\text { Exports to EU }\end{array}$ & $\begin{array}{r}\text { Share of tariff } \\
\text { paid by UK }\end{array}$ & $\begin{array}{r}\text { Share of UK } \\
\text { Imports }\end{array}$ & $\begin{array}{r}\text { Share of tariff } \\
\text { due to UK }\end{array}$ \\
\hline Austria & $1.21 \%$ & $0.78 \%$ & $1.31 \%$ & $1.14 \%$ \\
Belgium & $8.54 \%$ & $10.80 \%$ & $10.50 \%$ & $8.88 \%$ \\
Bulgaria & $0.25 \%$ & $0.18 \%$ & $0.19 \%$ & $0.18 \%$ \\
Cyprus & $0.28 \%$ & $0.01 \%$ & $0.03 \%$ & $0.41 \%$ \\
Czech Republic & $1.47 \%$ & $2.03 \%$ & $2.48 \%$ & $1.15 \%$ \\
Germany & $23.01 \%$ & $26.50 \%$ & $28.34 \%$ & $17.73 \%$ \\
Denmark & $1.71 \%$ & $2.92 \%$ & $1.63 \%$ & $1.82 \%$ \\
Spain & $6.46 \%$ & $6.88 \%$ & $6.12 \%$ & $7.26 \%$ \\
Estonia & $0.16 \%$ & $0.03 \%$ & $0.10 \%$ & $0.14 \%$ \\
Finland & $1.01 \%$ & $0.18 \%$ & $0.82 \%$ & $0.99 \%$ \\
France & $13.33 \%$ & $10.04 \%$ & $10.81 \%$ & $13.02 \%$ \\
Greece & $0.66 \%$ & $0.37 \%$ & $0.36 \%$ & $0.83 \%$ \\
Croatia & $0.10 \%$ & $0.04 \%$ & $0.07 \%$ & $0.10 \%$ \\
Hungary & $0.96 \%$ & $0.95 \%$ & $1.15 \%$ & $0.97 \%$ \\
Ireland & $12.56 \%$ & $10.37 \%$ & $5.05 \%$ & $19.25 \%$ \\
Italy & $6.37 \%$ & $6.65 \%$ & $7.30 \%$ & $6.64 \%$ \\
Lithuania & $0.20 \%$ & $0.29 \%$ & $0.34 \%$ & $0.17 \%$ \\
Luxembourg & $0.16 \%$ & $0.08 \%$ & $0.14 \%$ & $0.10 \%$ \\
Latvia & $0.16 \%$ & $0.06 \%$ & $0.16 \%$ & $0.11 \%$ \\
Malta & $0.28 \%$ & $0.03 \%$ & $0.05 \%$ & $0.31 \%$ \\
Netherlands & $12.97 \%$ & $11.23 \%$ & $12.73 \%$ & $10.92 \%$ \\
Poland & $2.73 \%$ & $4.41 \%$ & $4.02 \%$ & $2.45 \%$ \\
Portugal & $0.94 \%$ & $1.01 \%$ & $1.13 \%$ & $1.51 \%$ \\
Romania & $0.73 \%$ & $0.86 \%$ & $0.78 \%$ & $0.64 \%$ \\
Slovak Republic & $0.33 \%$ & $1.79 \%$ & $1.27 \%$ & $0.27 \%$ \\
Slovenia & $0.15 \%$ & $0.11 \%$ & $0.18 \%$ & $0.13 \%$ \\
Sweden & $1.25 \%$ & $2.93 \%$ & $2.91 \%$ \\
\hline Total & $100.00 \%$ & $100.00 \%$ & $100.00 \%$ & $100.00 \%$ \\
\hline & & & &
\end{tabular}


Figure 3: WTO Implied Tariffs on UK to EU Exports by Product

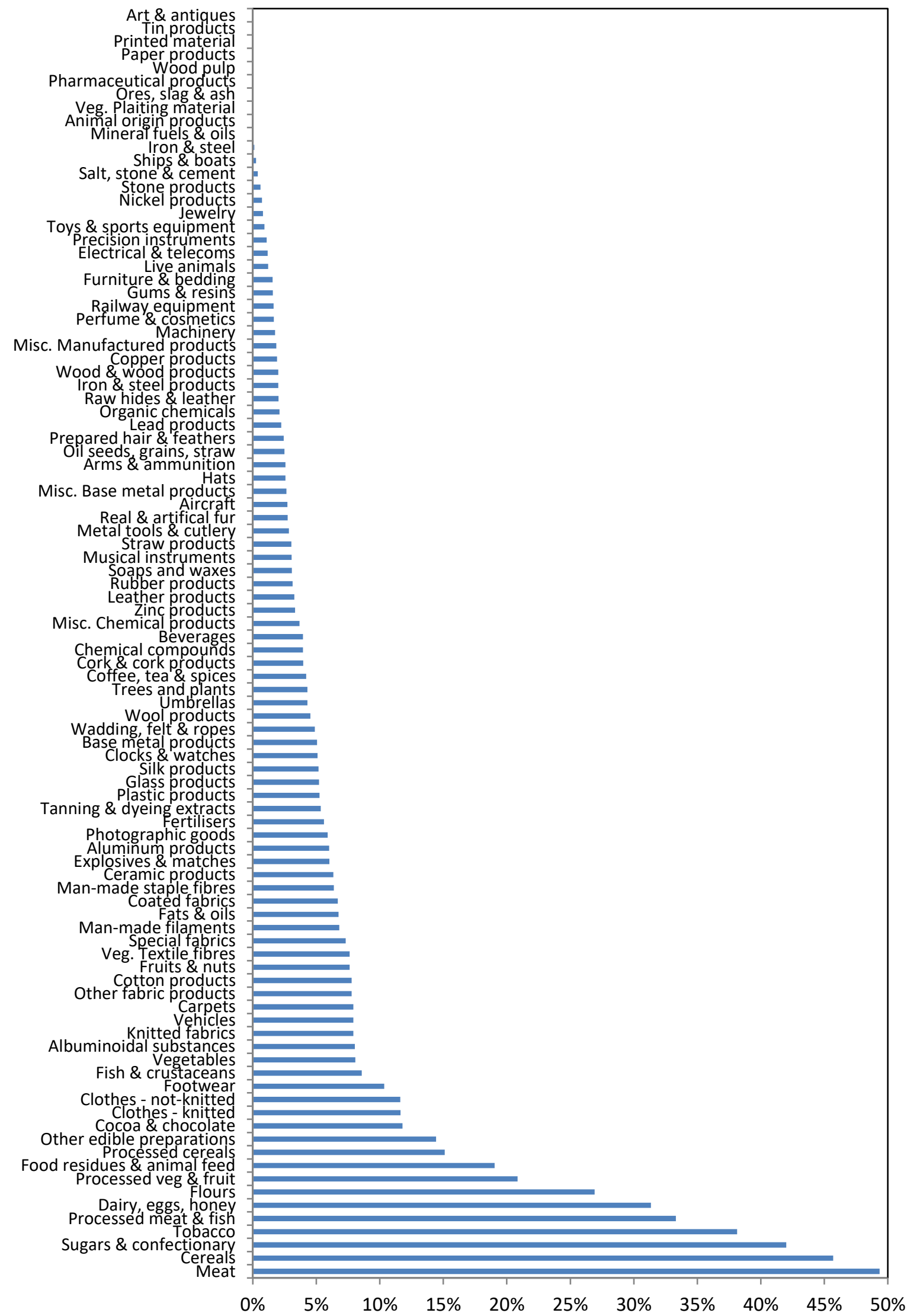


Figure 4: Correlation between Trade Share and Tariff

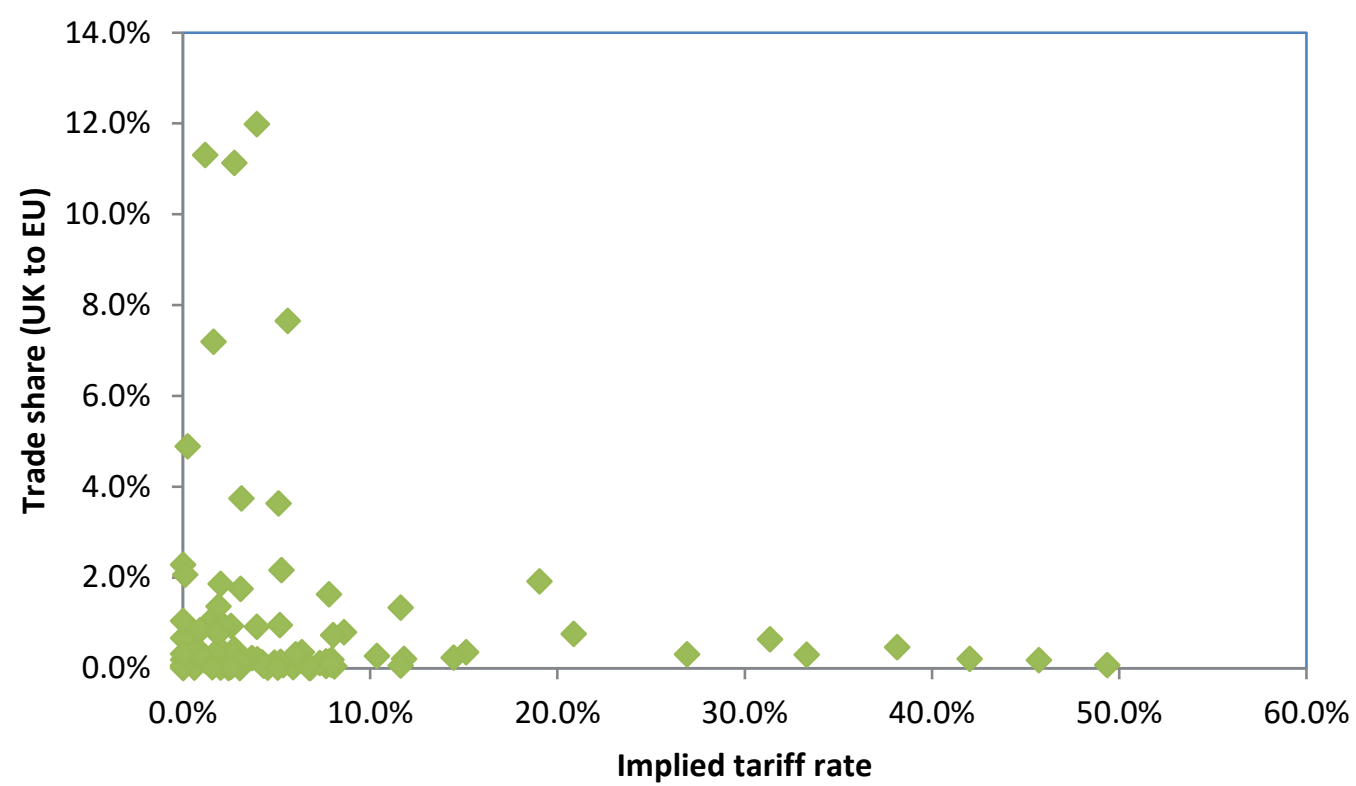

Overall, Figure 4 shows that there is no particular correlation evident between the tariff rate and the share of the sector in UK to EU trade (the EU-UK scatter plot is similar). In other words, we do not find any systematic pattern of higher tariffs on high or low trade shares, although none of the UK's most important exported sectors (those with trade shares over 7\% each) are amongst the group of 15 sectors that face the highest tariff rates.

Although there is no strong correlation between the tariff and trade share, it is of some interest to take a closer look at the details of the tariff rates across sectors and where they play an important role in UK trade. Tables 3 and 4 present two sub-sets of sectors - those with the highest tariff rates and those with the highest trade shares respectively. Only one sector appears on both tables - food residues and animal feed which has a tariff of $19 \%$ is the only high-tariff product included in the top 15 trade shares, albeit towards the bottom of the list representing under $2 \%$ of UK exports to the EU.

Importantly for the potential tariff exposure, the total share of all of the sectors listed as hightariff in Table 3 account for just over $7 \%$ of total UK exports to the EU. In contrast, in Table 4, we see that the top three products which combined account for one-third of exports would all face tariffs close to the lowest on the scale (1.18 to $3.95 \%)$. 


\begin{tabular}{lcc}
\hline & $\begin{array}{c}\text { Tariff rate } \\
\text { UK to EU }\end{array}$ & $\begin{array}{c}\text { Trade share } \\
\text { UK to EU }\end{array}$ \\
\hline Meat & $49.35 \%$ & $0.07 \%$ \\
Cereals & $45.71 \%$ & $0.18 \%$ \\
Sugars \& confectionary & $42.00 \%$ & $0.21 \%$ \\
Tobacco & $38.14 \%$ & $0.47 \%$ \\
Processed meat \& fish & $33.31 \%$ & $0.29 \%$ \\
Dairy, eggs, honey & $31.34 \%$ & $0.64 \%$ \\
Flours & $26.92 \%$ & $0.31 \%$ \\
Processed veg \& fruit & $20.86 \%$ & $0.75 \%$ \\
Food residues \& animal feed & $19.03 \%$ & $1.92 \%$ \\
Processed cereals & $15.11 \%$ & $0.35 \%$ \\
Other edible preparations & $14.44 \%$ & $0.24 \%$ \\
Cocoa \& chocolate & $11.79 \%$ & $0.20 \%$ \\
Clothes - knitted & $11.63 \%$ & $0.06 \%$ \\
Clothes - not-knitted & $11.62 \%$ & $1.34 \%$ \\
Footwear & $10.35 \%$ & $0.27 \%$ \\
\hline Sum of trade shares & & $7.28 \%$ \\
\hline
\end{tabular}

Table 4: Implied Tariff Rates of Highest Share Sectors

\begin{tabular}{lcc}
\hline & Tariff rate & Trade share \\
& UK to EU & UK to EU \\
\hline Chemical compounds & $3.95 \%$ & $11.99 \%$ \\
Electrical \& telecoms & $1.18 \%$ & $11.31 \%$ \\
Aircraft & $2.73 \%$ & $11.13 \%$ \\
Fertilisers & $5.60 \%$ & $7.65 \%$ \\
Railway equipment & $1.64 \%$ & $7.19 \%$ \\
Ships \& boats & $0.25 \%$ & $4.89 \%$ \\
Rubber products & $3.13 \%$ & $3.75 \%$ \\
Clocks \& watches & $5.11 \%$ & $3.63 \%$ \\
Pharmaceutical products & $0.00 \%$ & $2.28 \%$ \\
Plastic products & $5.26 \%$ & $2.16 \%$ \\
Iron \& steel & $0.11 \%$ & $2.06 \%$ \\
Food residues \& animal feed & $19.03 \%$ & $1.92 \%$ \\
Iron \& steel products & $2.00 \%$ & $1.86 \%$ \\
Soaps and waxes & $3.08 \%$ & $1.75 \%$ \\
Other fabric products & $7.79 \%$ & $1.63 \%$ \\
\hline Sum of trade shares & & $75.18 \%$ \\
\hline
\end{tabular}




\section{Trade Implications of Tariff-Induced Price Increases}

The application of any tariffs would be expected to feed through into prices. In the absence of information on market structure, we make the assumption that the full tariff amount would be incorporated into the price, although in practice some of the incidence could be absorbed by producers. We then examine what this tariff-induced price increase would do to trade values across all of the products being exported from the UK to the EU countries and vice versa. The total trade impact is a combination of the size of the price increase caused by the tariff and the sensitivity of each product to price changes. Given our focus on the heterogeneity of the impact of a WTO scenario on countries and products, it is important that we allow the trade price elasticity to vary. Unfortunately, this cannot be done at the very detailed product level but sector level elasticity estimates have been calculated by Imbs and Mejean (2016). ${ }^{1}$

These estimates provide a range of values for each sector - in Figure 5 we show the range of trade reductions associated with the mean, median, maximum and minimum values of elasticities for each sector. ${ }^{2}$ Thereafter, however, in looking at the detail of effects on countries and sectors, we take the conservative approach of focusing on the effects generated by using the median elasticity estimate for each sector. The median elasticity estimates range from a low of -2.8 for tobacco products to highs of -10.9 for measuring equipment and -10.5 for wearing apparel. Food products, which are particularly of interest given the very high tariffs that they attract, have a relatively high median elasticity of -6.1 .

Combining the price increases and elasticity estimates generates a fall in EU to UK trade by 30 $\%$ and a $22 \%$ reduction in UK to EU trade if median elasticity estimates are used. The mean elasticities are slightly higher and would generate falls of $37 \%$ in EU-UK trade and $27 \%$ in UK-EU trade. The upper and lower bounds of the estimates are given by the maximum elasticity estimates which would generate trade falls of 56\% and $45 \%$ in EU-UK and UK-EU trade respectively and the minimum estimates would result in trade declines of $17 \%$ and $12 \%$ respectively.

\footnotetext{
${ }^{1}$ Imbs and Mejean (2016) define their sectors at the ISIC 2-digit level which we match to our HS products using concordances available from Eurostat's Ramon database of nomenclatures: ec.europa.eu/eurostat/ramon

${ }^{2}$ Note that this makes an assumption that all sectors simultaneously have the mean elasticity or the minimum elasticity etc.
} 
Figure 5: Trade Reductions and Elasticity Assumptions

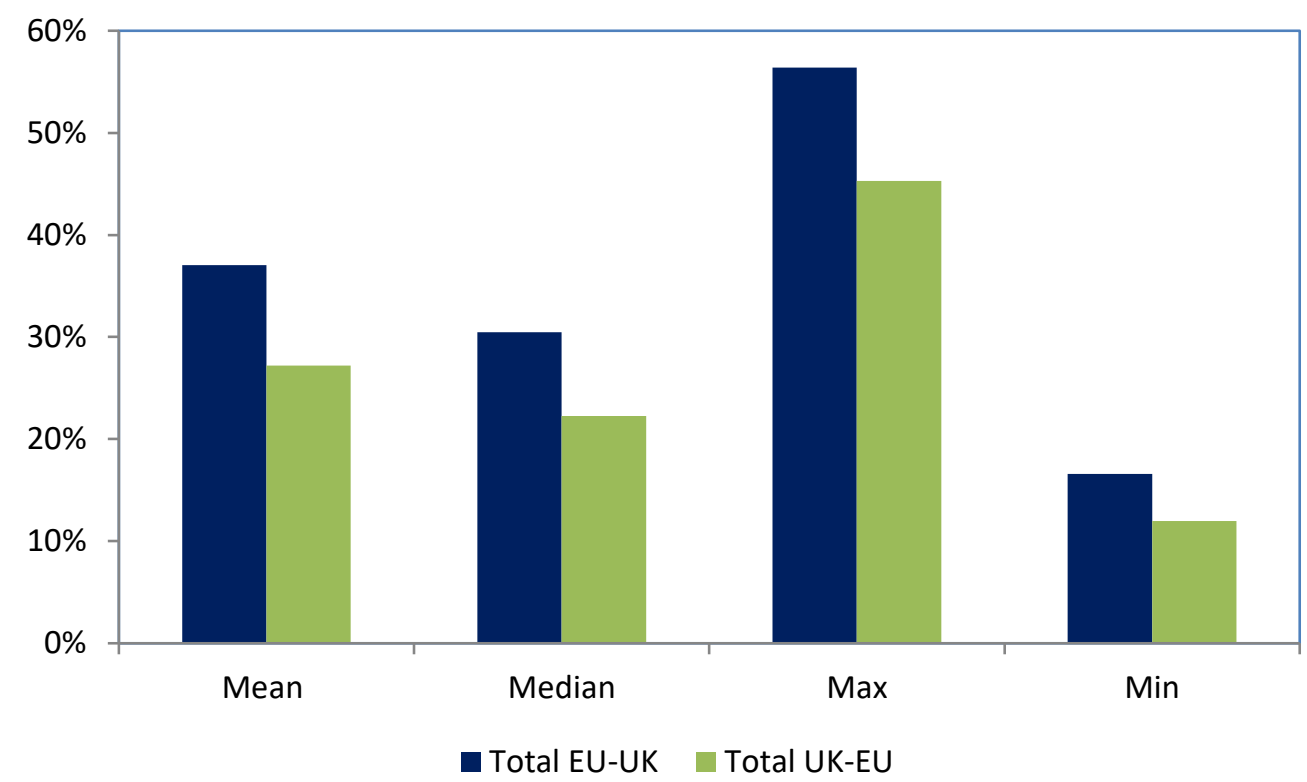

While these are substantial aggregate effects, the main focus of this paper is the uneven impact of the Brexit WTO scenario given the differing structures of trade with the UK across EU countries. Putting together the tariff rates, which we saw earlier varied considerably across countries, with the elasticity response to the price increase, gives us country by country estimates of the trade reaction to a WTO scenario. Figure 6 shows the extent to which the trade reductions would impact on each of the EU members. The variation in the effect on exports to the UK is greater than that of imports from the UK given that the structure of imports from the UK varies rather less across countries than does the composition of each country's exports to the UK. Countries such as Cyprus, Estonia, Finland and Latvia would be relatively modestly affected by the implementation of WTO tariffs, seeing their exports to the UK fall by between $6 \%$ and $11 \%$. Countries that would see export reductions to the UK well in excess of the average effect of a 30\% fall are Denmark, Spain and Romania, who would all see reductions in the order of $40 \%$, and Slovakia which would be the most severely affected in terms of its exports to the UK project to decline by $59 \%$. 


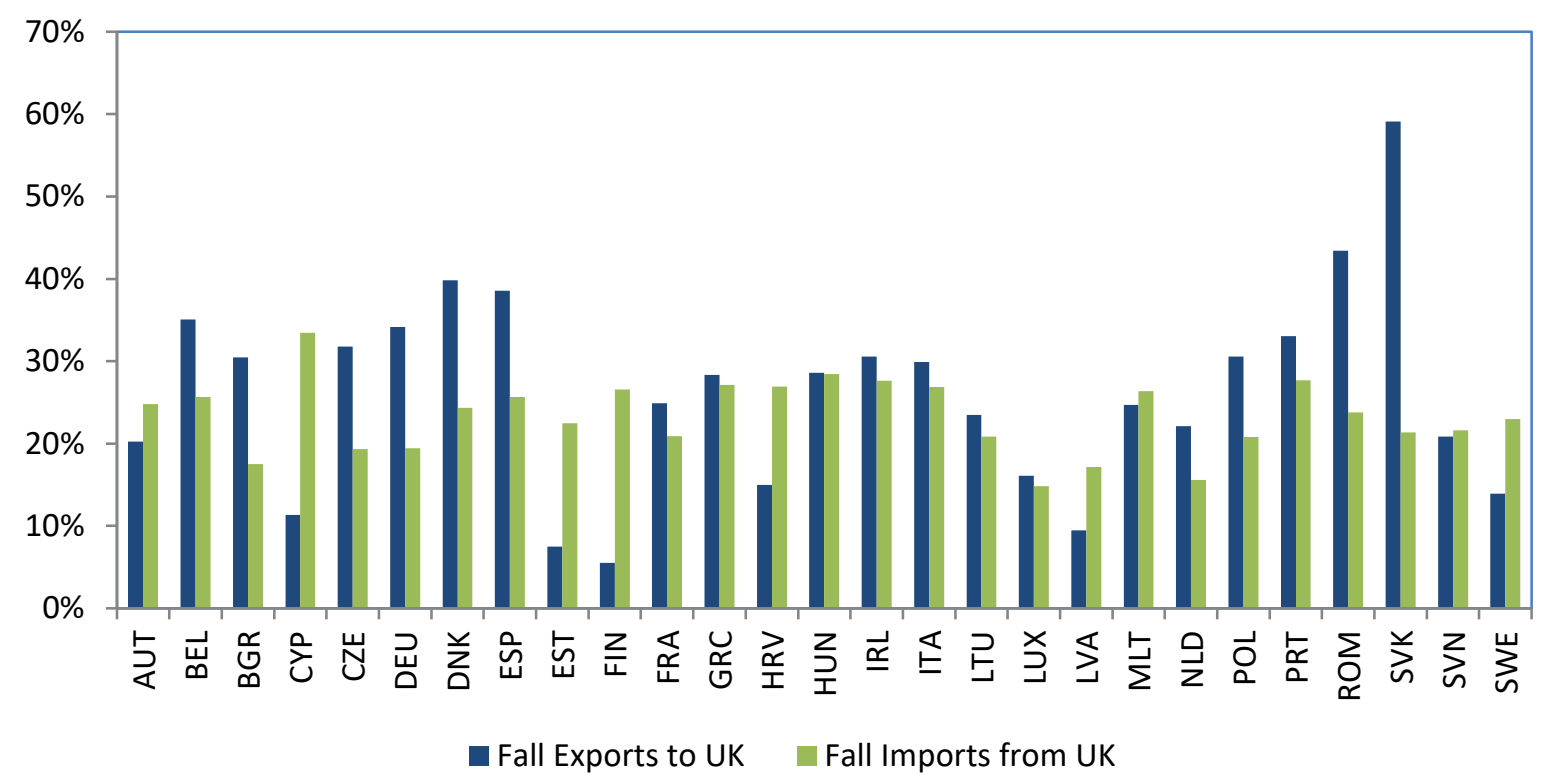

The high tariff rates associated with some products - primarily food and clothing - when combined with the price elasticity response would result under our calculations in a number of product lines ceasing to be traded altogether. As shown in Figure 7 around 10\% of the over 4000 products exported by the UK to the EU would be dropped as a result of the price increase induced by WTO level tariffs. The variation in the percentage of product lines dropped by the UK is fairly stable across EU partners. There is variation in the number of product lines shipped to each partner country with a broader product range in general sold to the larger countries; for example, the UK sells over 4,400 products to Germany and France compared to 2,200 to Croatia.

The impact on product lines exported again varies more for exports from EU countries to the UK, although this measure is not entirely correlated with the overall projections of the size of the trade impact as the products wiped out may be those already trading a relatively small volume. For example, Cyprus experiences the largest decrease in number of products exported (31\%) although its total trade reduction was a relatively modest $11 \%$. On the other end of the scale, Estonia remains one of the least exposed countries by this metric as well as having one of the lowest falls in the trade value estimates. Other countries that would see a substantial percentage of products likely to no longer be viable as exports to the UK are Malta, Bulgaria and Latvia. 


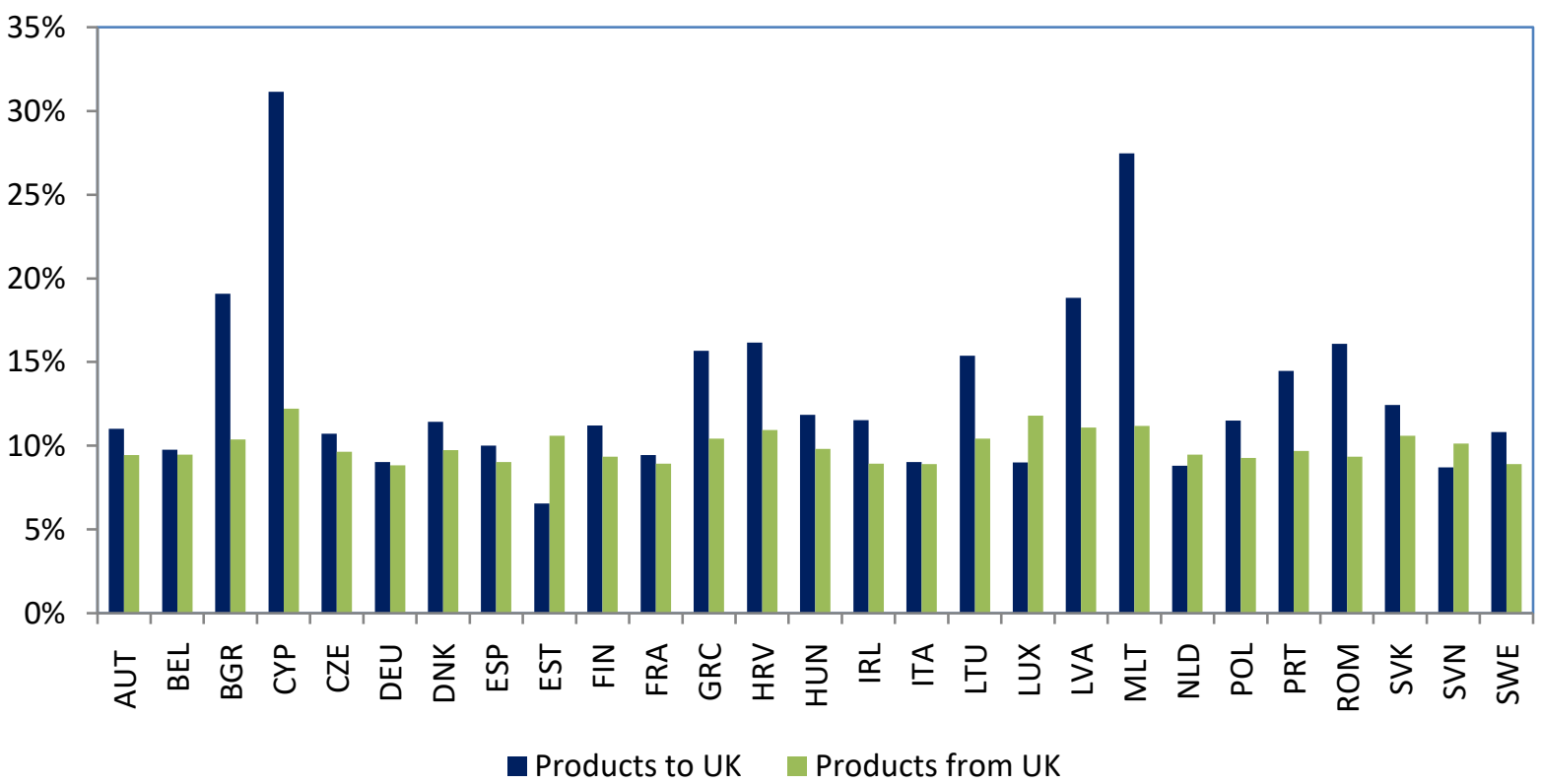

Driving the differences in the size of trade falls across countries are their trade compositions with the UK, specifically the combination of the size of the tariffs applied to different products with the elasticity of the trade response of those products. As we will see in the next two figures, the impact of the WTO scenario at a sector level results in trade reductions that range from no fall at all to reductions not far off 100\%. Figures 8 and 9 show the estimated reductions in trade (both to and from the UK) by sector. For ease of presentation, Figure 8 shows sectors that would have trade reductions over $20 \%$ (ranked according to the size of the EU-UK trade impact) and Figure 9 shows the relatively less affected sectors with trade falls lower than $20 \%$.

The EU to UK trade reductions and those from the UK to EU are broadly similar to one another when we look sector by sector in these figures. However, there are some exceptions (beverages, cereals and live animals for example show quite differently sized effects depending on the direction of the trade flow) because we are building these sectoral estimates up from the product level trade structure and tariff rates can vary quite significantly with each sector.

A number of sectors where the bulk of products attract low or zero tariffs correspondingly have almost no change in their trade flows in either direction. These include pharmaceuticals, paper and printed materials, while other sectors such as machinery and a range of metal-based products would decline by $10 \%$ to $20 \%$. At the other end of the impact scale, the high tariffs combined with a relatively elastic price response result in food and clothing sectors all being hit extremely hard by a WTO scenario. The two most affected sectors are both clothes (knitted and non-knitted) where trade both to and from the UK would fall by $99 \%$. The next ten most affected sectors are all food-based 
with falls of $68 \%$ for the dairy, eggs and honey sector and up to $95 \%$ for sugar and confectionary. Any country within the EU reliant on trade with the UK in these sectors will clearly be disproportionately hit if a WTO scenario is the default trade arrangement

Figure 8: Sectors with Trade Reductions over $\mathbf{2 0 \%}$

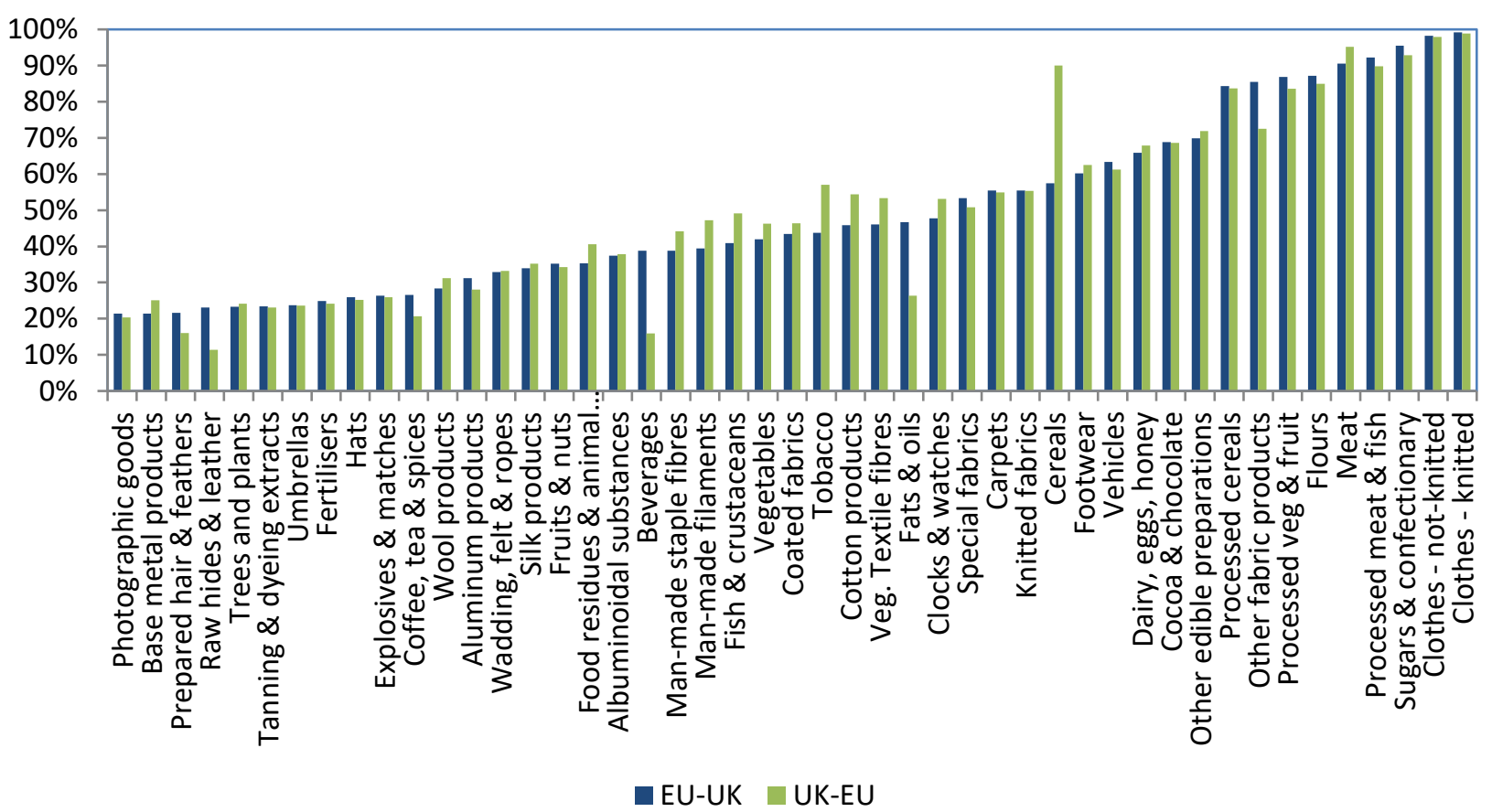

Figure 9: Sectors with Trade Reductions under $20 \%$

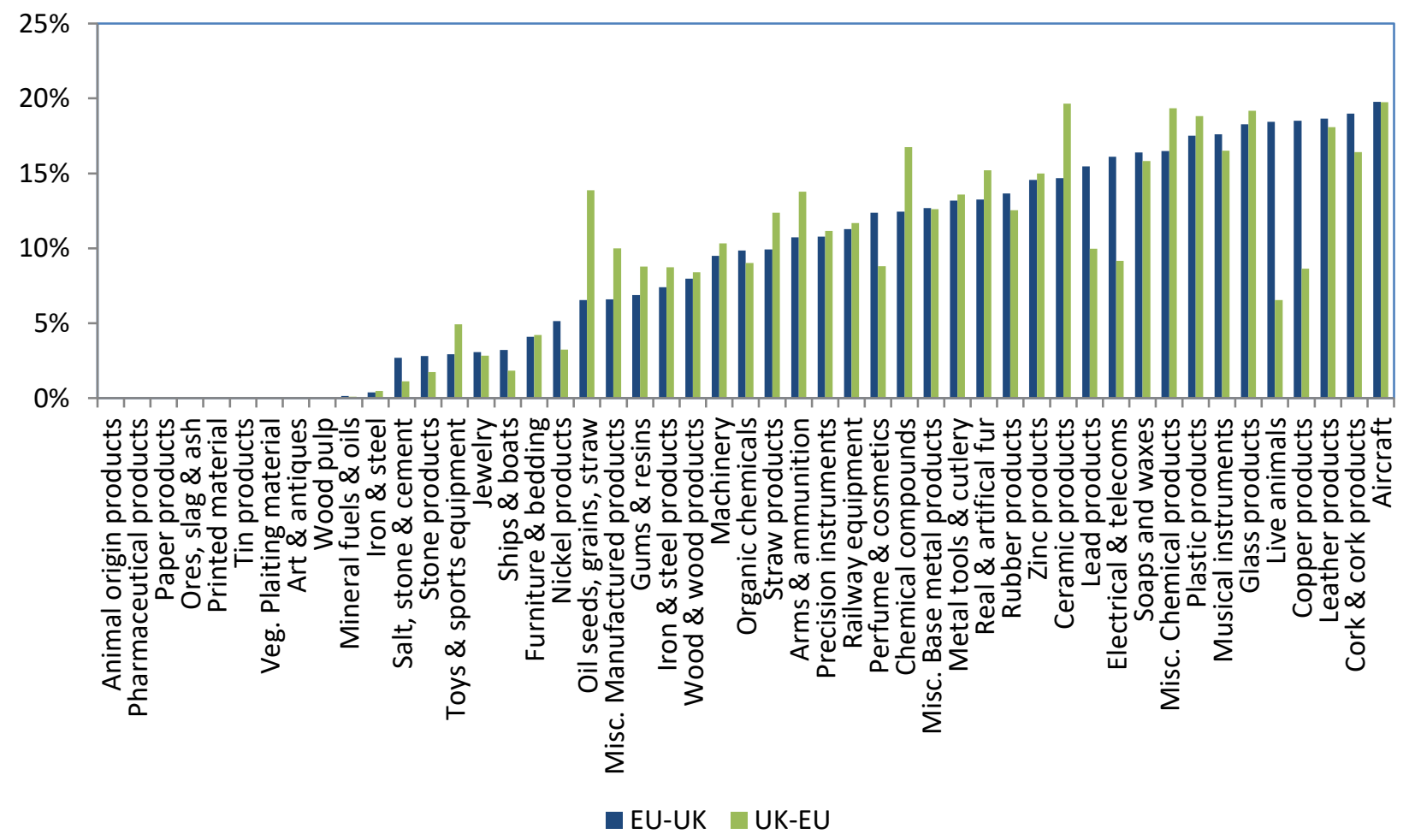


After the food groups, one of the most affected sectors is vehicles. Despite not having one of the highest tariffs (7.9\%) it is a sector that has one of the higher sensitivities to trade price changes (median elasticity of -8.0). It is also a highly traded sector that accounts for a significant share of exports from a number of countries, so the size of its trade reduction will have a relatively high weight in the total trade adjustment.

We have focused so far on the extent of the reductions in bilateral trade between each EU member state and the UK. In order to get a full picture of the impact on each country, it is also important to consider how large a share of total exports and imports is accounted for by the UK. Table 5 presents the size of the reductions in each member states trade with the UK (exports to the UK in the first column, imports from the UK in the third column) which were already discussed in Figure 6 above. The table then scales these reductions in UK trade by the share of the UK in the country's total trade in the second and last columns). This re-orders the exposure levels of the different countries. Both Ireland and Poland are estimated to have an almost identical fall of $30.6 \%$ in their exports to the UK. However, because the UK is a much larger export partner for Ireland, this corresponds to a $4.17 \%$ fall in total Irish exports whereas the total reduction in Polish exports is just over $2 \%$. Slovakia has the highest estimated reduction in exports to the UK and is still one of the most exposed when we look at the change in total exports but the impact is scaled down considerably.

A number of countries would see minimal impacts in total trade - Estonia, Finland, Latvia and Slovenia all have reductions of less than half of one per cent. Ireland is the most severely affected when total trade is used, followed by Belgium and Slovakia who also see reductions in excess of $3 \%$.

Looking at the effect on the UK of reductions in total exports, we see there are a number of the largest falls in flows with an individual partner country that do not translate into significant effects on total trade such as the $33 \%$ fall in exports to Cyprus which would contribute a $0.04 \%$ fall in the total. The just under $20 \%$ fall in exports to Germany is of considerably more weight, impacting total exports by almost $2 \%$.

The final row of Table 5 summarises the total impact on trade flows of the imposition of a WTO tariff regime. Exports from the EU to the UK are estimated to fall by $30 \%$ and exports from the UK to the EU by $22 \%$. Each EU member is each facing a reduction in trade with a single export partner in this scenario so the effect on total EU exports is a reduction of $2.13 \%$ (a trade-weighted average of each country's reduction in column 2). However, as the UK is facing reductions in 27 trade flows, the impact on its total exports is the sum of all the individual effects in the last column which gives an overall reduction in exports of $9.8 \%$. 
Table 5: Trade Reductions relative to Bilateral and World Trade

\begin{tabular}{lrrrr}
\hline & $\begin{array}{r}\text { \% of trade } \\
\text { with UK }\end{array}$ & $\begin{array}{r}\text { \% of total } \\
\text { trade }\end{array}$ & $\begin{array}{r}\text { \% UK trade with } \\
\text { EU partner }\end{array}$ & $\begin{array}{r}\text { \% of total } \\
\text { UK trade }\end{array}$ \\
\hline Austria & $20.22 \%$ & $0.62 \%$ & $24.77 \%$ & $0.13 \%$ \\
Belgium & $35.08 \%$ & $3.13 \%$ & $25.67 \%$ & $0.97 \%$ \\
Bulgaria & $30.45 \%$ & $0.78 \%$ & $17.52 \%$ & $0.02 \%$ \\
Cyprus & $11.33 \%$ & $1.14 \%$ & $33.44 \%$ & $0.04 \%$ \\
Czech Rep. & $31.78 \%$ & $1.67 \%$ & $19.32 \%$ & $0.13 \%$ \\
Germany & $34.14 \%$ & $2.54 \%$ & $19.44 \%$ & $1.98 \%$ \\
Denmark & $39.81 \%$ & $2.53 \%$ & $24.35 \%$ & $0.18 \%$ \\
Spain & $38.56 \%$ & $2.87 \%$ & $25.64 \%$ & $0.73 \%$ \\
Estonia & $7.49 \%$ & $0.19 \%$ & $22.48 \%$ & $0.02 \%$ \\
Finland & $5.54 \%$ & $0.27 \%$ & $26.59 \%$ & $0.12 \%$ \\
France & $24.88 \%$ & $1.56 \%$ & $20.92 \%$ & $1.23 \%$ \\
Greece & $28.35 \%$ & $1.20 \%$ & $27.15 \%$ & $0.08 \%$ \\
Croatia & $14.97 \%$ & $0.26 \%$ & $26.94 \%$ & $0.01 \%$ \\
Hungary & $28.60 \%$ & $1.11 \%$ & $28.44 \%$ & $0.12 \%$ \\
Ireland & $30.56 \%$ & $4.17 \%$ & $27.61 \%$ & $1.53 \%$ \\
Italy & $29.88 \%$ & $1.65 \%$ & $26.85 \%$ & $0.76 \%$ \\
Lithuania & $23.51 \%$ & $1.05 \%$ & $20.84 \%$ & $0.02 \%$ \\
Luxembourg & $16.08 \%$ & $0.62 \%$ & $14.82 \%$ & $0.01 \%$ \\
Latvia & $9.45 \%$ & $0.48 \%$ & $17.15 \%$ & $0.01 \%$ \\
Malta & $24.71 \%$ & $1.59 \%$ & $26.37 \%$ & $0.03 \%$ \\
Netherlands & $22.10 \%$ & $1.98 \%$ & $15.59 \%$ & $0.89 \%$ \\
Poland & $30.58 \%$ & $2.08 \%$ & $20.78 \%$ & $0.25 \%$ \\
Portugal & $33.04 \%$ & $2.22 \%$ & $27.70 \%$ & $0.11 \%$ \\
Romania & $43.42 \%$ & $1.89 \%$ & $23.77 \%$ & $0.08 \%$ \\
Slovakia & $59.11 \%$ & $3.27 \%$ & $21.35 \%$ & $0.03 \%$ \\
Slovenia & $20.83 \%$ & $0.47 \%$ & $22.93 \%$ & $0.01 \%$ \\
Sweden & $13.93 \%$ & $1.00 \%$ & $22.25 \%$ & $0.33 \%$ \\
\hline Total & $30.47 \%$ & $2.13 \%$ & & $9.83 \%$ \\
\hline & & & &
\end{tabular}

\section{Summary and Conclusions}

This paper digs into the detail beneath a WTO scenario for post-Brexit UK-EU trade. While the aggregate economic impact of such a scenario have been investigated the wide variation in tariff rates, and hence heterogeneity in sectoral and country-level impacts, has not been previously studied. Taking the 5200 products listed in the EU external tariff schedule and applying them symmetrically to EU-UK trade shows effective tariff rates ranging from $2 \%$ to $11 \%$ by country. Across sectors, the variation is more dramatic, ranging from $0 \%$ to $50 \%$ reflecting the differences in products traded. Combining these tariff-induced price increases with elasticity response estimates, we calculate the total effect on trade by country. The EU's 
exports to the UK would fall by $30 \%$ representing a $2 \%$ reduction in its total world trade. Ireland and Belgium would be the most exposed, losing $4 \%$ and $3.1 \%$ of their total exports respectively, whereas some countries such as Estonia and Finland would see reductions in their total trade of less than $0.3 \%$. The UK's exports to the EU would fall by $22 \%$ but as these reductions apply to 27 trading partners, the aggregate effect is larger than that of the EU with the UK facing a fall in its total trade of $9.8 \%$. Trade in some specific sectors, such as food and textiles would be close to wiped out while others would be almost unaffected. The severity of the impact is therefore driven critically by the product structure of current trade flows between the UK and each individual EU member.

As a final note on considerations that are beyond the scope of this paper; we examine specifically the impact of WTO tariffs on UK-EU trade but maintain the assumption that the UK stays a member of the customs union with the EU. This means that we do not examine the impact of any potential changes in tariffs that the UK might apply to other countries in the event of no longer being tied to the common external tariff it currently applies as an EU member. A decision by the UK to deviate from the common external tariff means removing itself from the EU customs union which in turn means that customs checks and documentation to comply with rules of origin would need to be implemented in order to prevent third countries from transiting goods through the UK to avoid higher EU tariffs (Sapir, 2016). This example highlights further the very broad range of channels through which decisions on the path of Brexit could impact on not just European and British but also world trade flows. 


\section{References}

Baker, J., Carreras, O., Kirby, S., Meaning, J., and R. Piggott (2016b), "Modelling events: The shortterm impact of leaving the EU”, Economic Modelling, Vol. 58, pp. 339-350.

Barrett, A., Bergin, A., FitzGerald, J., Lambert, D., McCoy, D., Morgenroth, E., Siedschlag and Z. Studnicka (2015), Scoping the Possible Economic Implications of Brexit on Ireland. Research Series No. 48. Dublin; Economic and Social Research Institute.

Bergin, A., Garcia-Rodriguez, A., McInenrey, N., Morgenroth, E., and D. Smith (2017) "Modelling the Medium to Long Term Potential Economic Impact of Brexit on Ireland", Economic and Social Review, Vol. 48(3), pp. 305-316

Bollen, J., Meijerink, G., and H. A. Rojas-Romagosa (2016) Brexit Affects the Netherland more than many EU Countries/ Free Trade Agreement UK/EU lowers Costs. CPB Policy Brief. 2016/17. Amsterdam: CPB.

Caporale, G.M., C. Rault, R. Sova and A. Sova (2009) "On the bilateral trade effects of free trade agreements between the EU-15 and the CEEC-4 countries", Review of World Economics Volume 145(2), pp 189-206.

Cipollina, M., D.L. Debucquet and L. Salvatici (2016) "The tide that does not raise all boats: an assessment of EU preferential trade policies" Review of World Economics doi:10.1007/s10290016-0270-0.

Ebell, M., Hurst, I., and J. Warren (2016), "Modelling the long-run economic impact of leaving the European Union", Economic Modelling, Vol. 59, pp. 196-209

Donnellan, T., and K. Hanrahan (2016), Brexit: Potential Implications for the Irish Agri-Food Sector. Athenry: Teagasc

EC (2016), "The Economic Outlook after the UK Referendum: A First Assessment for the Euro Area and the EU". Institutional Paper 032. Brussels: European Commission.

HM Treasury (2016a), HM Treasury analysis: the immediate economic impact of leaving the EU. London: HM Treasury.

HM Treasury (2016b), HM Treasury analysis: the long-term economic impact of EU membership and the alternatives. London: HM Treasury.

HM Government (2017), Future Customs Arrangements: A Future Partnership Paper. London: HM Government.

Hobolt, Sara B. (2016). "The Brexit vote: a divided nation, a divided continent", Journal of European Public Policy, Vol.23(9), pp. 1259-1277

Imbs, Jean and Isabelle Mejean (2016). "Trade Elasticities", Review of International Economics, 21(X), 00-00, 2016, DOI:10.1111/roie.12270

Kierzenkowski, R., Pain, N., Rusticelli, E., and Zwart, S. (2016), The Economic Consequences of Brexit: A Taxing Decision. OECD Economic Policy Paper, No. 16. Paris: OECD. 
Los, B., McCann, P., Springford, J., and M. Thissen (2017) "The mismatch between local voting and the local economic consequences of Brexit", Regional Studies, Vol. 51(5), pp. 786-799.

Mathews, A., (2015) "Implications of British exit from the EU for the Irish agri-food sector", Trinity Economic Papers No. 0215. Dublin: Trinity College Dublin.

Sapir, André (2016). "Should the UK pull out of the EU customs union?", Brugel blog post, $1^{\text {st }}$ August 2016, http://bruegel.org/blog/ 